\title{
Comparative Study on Antioxidant Activities, Total Phenolic Compound and Pigment Contents of Tropical Spirulina platensis, Gracilaria arcuata and Ulva lactuca Extracted in Different Solvents Polarity
}

\author{
Jelita Rahma Hidayati ${ }^{1 *}$, Ervia Yudiati $^{1,2}$, Delianis Pringgenies $^{1}$, Diah Tri Oktaviyanti ${ }^{1}$, \\ Alief Putri Kusuma ${ }^{1}$ \\ ${ }^{1}$ Department of Marine Science, Faculty of Fisheries and Marine Science, Diponegoro University, \\ Tembalang, Semarang 50275 \\ ${ }^{2}$ Laboratory of Tropical Marine Biotechnology, Diponegoro University, Tembalang, Semarang \\ 50275
}

\begin{abstract}
These study aimed to determine antioxidant activity, total phenolic compound and pigment content of tropical S. platensis, G. arcuata and $U$. lactuca. S. platensis was extracted with aquadest (SPA), while $G$. arcuata and $U$. lactuca were extracted with n-hexane (GAH and ULH), ethyl-acetate (GAE and ULE) and methanol (GAM and ULM). The $\mathrm{IC}_{50}$ value was used to calculate the ability of extract to inhibit free radicals using DPPH $(515 \mathrm{~nm})$. The TPC was determined using Folin-Ciocalteu $(725 \mathrm{~nm})$. Phycocyanin $(620 \mathrm{~nm})$, phycoerythrin $(652 \mathrm{~nm})$, allophycocyanin $(562 \mathrm{~nm})$, carotenoid $(470 \mathrm{~nm})$ and chlorophyll $(645 \mathrm{~nm}$ and $662 \mathrm{~nm})$ were measured based on color intensity. The results indicated that SPA was able to inhibit free radicals $(46.12 \pm 2.03 \%)$, contains TPC $(26.64 \pm 0.16 \mathrm{mg} / \mathrm{GAE}$ samples $)$ and dominated by phycocyanin pigments $(0.301 \pm 0.09 \mathrm{mg} / \mathrm{g})$. G. arcuata extracted with ethyl-acetate (GAE) showed the best value with $\mathrm{IC}_{50}$ $136.267 \pm 0.28 \mathrm{ppm}$, TPC $303.507 \pm 1.155 \mathrm{mg} / \mathrm{GAE}$ samples, carotenoid $0.528 \pm 0.009 \mu \mathrm{mol} / \mathrm{g}$ and chlorophyll a $2.845 \pm 0.069 \mathrm{mg} / \mathrm{g}$. The $U$. lactuca extracted with ethyl-acetate also showed the best value with $\mathrm{IC}_{50}$ $462.560 \pm 2.44 \mathrm{ppm}$, TPC $210.129 \pm 1.387 \mathrm{mg} / \mathrm{GAE}$ samples, carotenoid $0.442 \pm 0.046 \mu \mathrm{mol} / \mathrm{g}$ and chlorophyll a $9.216 \pm 0.103 \mathrm{mg} / \mathrm{g}$. This results conlcuded that macroalgae extracted with ethyl acetate had better activity which categorized as moderate antioxidant.
\end{abstract}

\section{Introduction}

Marine algae that grow in the tropical area are exposed in strong ultraviolet radiation and combination of light and oxygen throughout the year. To avoid ultraviolet damage, these algae have protective antioxidative defense by change their metabolism, synthesize pigment

*Corresponding author: jelitarahmahidayati@gmail.com 
and produce some active compounds. So, that the oxydative damage does not influence the structural components [1]. Ttropical algae may possess a large number of active compounds as antioxidants, UV-absorbing matrix-metalloproteinase inhibitors, anti-aging, and immunomodulatory activities [2].

Spirulina platensis is one of blue-green microalga, which has a complex composition. The nutritional value of Spirulina is well recognized by its high protein content $(60-70 \%$ by dry weight) and its richness vitamins, minerals, essential fatty acids and other nutrients especially vitamin $\mathrm{B}_{12}, \beta$-carotene and minerals such as iron [3]. Spirulina is a source of chlorophyll, and carotenoids [4] and containing phycobiliprotein compounds, consists of phycocyanin, allophycocyanin, and phycoeritrin. Its components have positive benefits for human health indications and can be used as a source of antioxidant [5]. Besides microalgae, macroalgae such as Gracilaria arcuata and Ulva lactuca are the alternative source which also provides several bioactive compounds used in biological activities such as antibacterial, anti-inflammatory and antioxidant activity [6].

Antioxidant can slows or prevents the oxidative or damage from oxygen process caused by free radicals, significantly [7]. The free radicals include superoxide anions $\left(* \mathrm{O}_{2}\right)$, hydroxyl radicals $\left(\mathrm{OH}^{*}\right)$, alkoxyl radicals $\left(\mathrm{RO}^{*}\right)$, peroxyl radical $\left(\mathrm{ROO}^{*}\right),(\mathrm{OONO} *)$, hydrogen peroxide $\left(\mathrm{H}_{2} \mathrm{O}_{2}\right)$ and singlet oxygen $\left({ }_{1} \mathrm{O} 2\right)$, which triggers a chain reaction [8]. This free radical is one of the main cause of metabolic injury, accelerating aging, cancer, cardiovascular diseases, neurodegenerative diseases and inflammation [9]. Antioxidants are classified as synthetic and natural antioxidants. Synthetic antioxidants can induced the carcinogenic effect if used excessively [10]. But, natural antioxidant from marine algae has not side effects and non-toxic in nature [11]. It makes the source of natural antioxidant compounds important to explore and develop.

S. platensis was able to inhibit $77.47 \%$ free radicals and has antioxidant activity at 1000 $\mathrm{mg} / 100 \mathrm{ml}$ concentration. S. platensis contains a number of natural pigments such as chlorophyll, $\beta$-carotene, phycoerythrin and phycocyanin [12]. Gracilaria sp. had an $\mathrm{IC}_{50}$ value of $72.9 \mu \mathrm{g} / \mathrm{mL}$ and had total phenolic content of $1.509 \pm 0.023 \mathrm{mg}$ GAE/g. Gracilaria species are important for the industrial and biotechnological because they have bioactive compounds such as carotenoid, feofotin, chlorophyll a, chlorophyll b, xantophyll, alkaloid, flavonoid, saponin, fenol, triterpenoid [13].

Ulva lactuca was able to inhibit $29.4 \%$ free radicals at concentration $50 \mu \mathrm{g} / \mathrm{mL}$ and had $0.45 \mathrm{mg} / 100 \mathrm{~g}$ of total phenols in summer session [14]. U. lactuca contains bioactive compounds such as polyphenols, flavonoids [14], neoxanthin steroids and fatty acids [15], xanthophyll $\beta$-carotene, lutein and lycopene which can be used as a source of natural antioxidant [16]. This study aimed to determine antioxidant activity, total phenolic content and pigment content of tropical S. platensis, G. arcuata and U. lactuca.

\section{Materials and methods}

\subsection{Sample extraction}

The S. platensis powder sample was collected from Brackishwater Aquaculture Development Centre, Jepara. Extraction of the $S$. platensis. was done by maceration using aquadest (SPA). One gram S. platensis powder macerated with warm aquadest and boiled for 2 hours. The sample was then macerated in room temperature for 24 hours and filtered. Filtrate then centrifugated in $3500 \mathrm{rpm}$ for 15 minutes and evaporated by cool dried method.

The G. arcuata and U. lactuca sample was collected from Krakal Waters, Yogyakarta. In the laboratory, the samples were washed using fresh water and dried up at room temperature. Extraction of G. arcuata and U. lactuca was done by gradual maceration using solvents with 
different polarity ie. n-hexane (non-polar) (GAH and ULH), ethyl acetate (semi-polar) (GAE and ULE) and methanol (polar) (GAM and ULM) [18]. A 250 gram dry sample was cut into small pieces $( \pm 5 \mathrm{~mm})$ and macerated using $1000 \mathrm{~mL}$-hexane solvent for 24 hours at \pm $27^{\circ} \mathrm{C}$, then filtered. The residue is remacerated for 24 hours and refiltered. The n-hexane filtrate was concentrated using a rotary evaporator at $35^{\circ} \mathrm{C}$. The seaweed residue was reextracted with ethyl acetate and methanol solvent in a similar manner [19]. The extract was then concentrated and cool dried and stored in the refrigeration for the next test.

\subsection{Determination of DPPH maximum absorbance}

As much as $4 \mathrm{mg}$ DPPH (2,2-diphenyl-1-picrylhydrazyl) was dissolved in $100 \mathrm{ml}$ of methanol to produce a DPPH (2,2-diphenyl-1-picrylhydrazyl) solution with a concentration of 0.101 $\mathrm{mM}$. The absorbance of this solution was observed using a spectrophotometer (Shimadzu $\mathrm{UV}-1280$ ) at a wavelength of $400-800 \mathrm{~nm}$ [20].

\subsection{The assessment of antioxidant activity}

Antioxidant activity determination was carried out using spectrophotometric methods (Costa et al., 2018). A total of $3 \mathrm{~mL}$ of the test solution was added with $1 \mathrm{~mL}$ of DPPH $0.1 \mathrm{mM}$. The solution was incubated for 30 minutes and then measured the absorbance at the maximum wavelength. The percentage of inhibition is calculated using the formula [21].

Inhibition percentage $=\frac{(\text { Absorbance of DPPH }- \text { Absorbance of DPPH }+ \text { Extract })}{\text { Absorbance of DPPH }} \times 100 \%$

The radical scavenging activity of $S$. platensis water extracts were expressed as inhibition percentage of DPPH. While, the inhibition percentage data of G. arcuata and U. Lactuca was plotted to constructed the linear regression equation and determined the $\mathrm{IC}_{50}$ value.

\subsection{Measurement of total phenolic content}

Determination of total phenolic compound of samples was performed using Folin-Ciocalteu and gallic acid reagents as standard [22]. A $5 \mathrm{mg}$ gallic acid is dissolved in $5 \mathrm{~mL}$ ethanol to obtain a $1000 \mathrm{ppm}$ stock solution. The stock solutions were diluted using methanol p.a. to obtain some series of concentrations $(5,10,20,30$ and $40 \mathrm{mg} / \mathrm{L})$. A $200 \mu \mathrm{L}$ of each concentration was taken, and then followed by the addition $10 \mathrm{~mL}$ of aquadest and $1 \mathrm{~mL}$ of Folin-Ciocalteu reagent. The solution was left for 5 minutes then added $1 \mathrm{~mL}$ of $5 \% \mathrm{Na}_{2} \mathrm{CO}_{3}$ solution and incubated at room temperature for 1 hours in dark conditions [23]. Absorbance was measured using a spectrophotometer (Shimadzu UV-1280) at a wavelength of $725 \mathrm{~nm}$ [24]. The value of total phenolics is expressed in mg Galic Acid Equivalent (GAE)/1000 g) [25].

\subsection{Assessment of chlorophyll a and carotenoids compounds}

Each extract was dissolved with acetone p.a at $100 \mathrm{ppm}$ and measured at a wavelength of 645 $\mathrm{nm}, 662 \mathrm{~nm}$ and $470 \mathrm{~nm}$ [26]. Most carotenoids absorb lights in the region between 400 and $500 \mathrm{~nm}$, while chlorophylls absorb light at 645 and $662 \mathrm{~nm}$ at room temperature [27].

The content of chlorophyll a and carotenoids is calculated based on the following formula [28]:

$$
\text { Chlorophyll a }=11.75 \times \text { A662 }-2,350 \times \text { A645 }
$$


Carotenoid $=\frac{1000 \times \mathrm{A} 470-2.270-81.4(18.61 \mathrm{~A} 645-3.960 \mathrm{~A} 662)}{227}$

\subsection{Assessment of phycobiliproteins compounds}

Phycobiliproteins was extracted using the freeze thawing method from dry biomass of $S$. platensis powder. The sample was macerated with $1.5 \% \mathrm{CaCl}_{2}(1: 20)(\mathrm{w} / \mathrm{v})$ and homogenized with vortex for 1 minute. Samples are freezing in the freezer $\left(-4{ }^{\circ} \mathrm{C}\right)$ for 12 hours, followed by thawing for 12 hours at room temperature [29]. The freeze thawing process is carried out 2 cycles. Filtrate was centrifuged at $4000 \mathrm{rpm}$ for 10 minutes, so that crude extract is obtained. The crude extract is analyzed by the content of Phycocyanin using a formula [24].

$$
\text { Phycocyanin }=\frac{\mathrm{A} 620-(0.474 \times \mathrm{A} 652)}{5.34}
$$

\subsection{Statistical analysis}

All data were subjected to one-way analysis of variance (ANOVA) at the level of significance of 0.05. A multiple comparison (LSD) test was used to examine significant differences among treatments using IBM SPSS Statistics 20 Computer Software. Before the analysis, the raw data were normalized using some transformation depend on the type of data.

\section{Results and discussion}

S. platensis was macerated using aquadest to dissolve the phycobiliprotein pigment, because phycobiliprotein is a natural pigment which is soluble in polar solvents [30]. While $G$. arcuata and $U$. Lactuca extracted step by step with n-hexane (non polar), ethyl acetate (semipolar) and methanol (polar) solvents. This is intended to get the maximum extraction. This because each solvent has the ability to dissolve compounds with the same polarity [31]. The general principle in solvent extraction "like dissolve like" means that suitable solvent only dissolve suitable substance with similar polarities [32].

It is necessary to measure wavelengths which have maximum absorbance value of DPPH, caused the type and specificity of the instrument used and the time of observation can cause the difference of maximum wavelength [33]. In this study, maximum absorbance value of DPPH is reached at a wavelength of $515 \mathrm{~nm}$. [34] [35].

Based on results of the antioxidant activity, SPA extract was able to inhibit $46.12 \pm 2.03$ $\%$ (Table 1) of free radicals. In this present research, the result of inhibition percentage was slightly lower than $77.47 \%$ [7]. Its because the extract produced is not a pure compounand and presence of impurities. Furthermore, SPA was extracted in the form of dry powder. Actually, fresh samples will have antioxidant activity better than dry sample [36], since drying process are reported to have a negative effect to antioxidant compounds. 
Table 1. Radical Scavenging Activity, Total Phenolic Compound, Pigment of SPA

\begin{tabular}{|c|c|c|}
\hline Content & Unit & Value \\
\hline RSA & $\%$ & $46.2 \pm 2.03$ \\
\hline TPC & $\mathrm{mg} \mathrm{GAE} / \mathrm{g}$ sample & $26.64 \pm 0.16$ \\
\hline Phycocyanin & $\mathrm{mg} / \mathrm{g}$ & $0.30 \pm 0.09$ \\
\hline Allo-Phycocyanin & $\mathrm{mg} / \mathrm{g}$ & $0.372 \pm 0.01$ \\
\hline Phycoerytherin & $\mathrm{mg} / \mathrm{g}$ & $0.247 \pm 0.02$ \\
\hline
\end{tabular}

Radical scavenging capacity of extract related to their concentration of total phenolic content (TPC). Many polyphenols contribute significantly to the antioxidant activity and act as a high effective free radical scavengers. These are mainly due to their redox properties, which can play an important role in adsorbing and neutralizing free radicals [17].

Total phenolic content of SPA extract is $26.64 \pm 0.16 \mathrm{mg} \mathrm{GAE} / \mathrm{g}$ samples (Table 1.) This result is much higher than $2.936 \pm 0.063 \mathrm{mg} / \mathrm{g}$ GAE samples [37] and slightly lower than 31.9 $\mathrm{mg} / \mathrm{g}$ GAE sample [7]. The different result occurs because the total phenolic content of SPA are varied, depends on many factors (algal species, origin, growth conditions, etc.) [38]. The phenolic compounds was detected in spirulina is catechin, epicatechin, pyrocatechol [38], pyrogallol, gallic, protocatechouic and salicylic [39].

Antioxidant activity can also be affected by pigment content. Natural pigments phycobiliprotiens which occur in SPA are phycocyanin and allophycocyanin [40]. SPA have total phycobiliprotein content consisting of phycocyanin $1.3 \mathrm{mg} / \mathrm{g}$, allo phycocyanin 4.1 $\mathrm{mg} / \mathrm{g}$ and phycoerytherin $2.83 \mathrm{mg} / \mathrm{g}$ (Table 1 ).

The free radical scavenging activity of G. arcuata and U.lactuca extract was assessed by the DPPH assay. Based on results of the antioxidant activity of G. arcuata and U.lactuca extract, each solvent performed different $\mathrm{IC}_{50}$ values (Figure 1). A significant decrease in the concentration of DPPH radical was observed due to the scavenging ability of the seaweeds. This study showed the difference of solvent polarity (methanol, ethanol, ethyl acetate, and nhexane) exhibited the different antioxidant activity. The results showed that the best $\mathrm{IC}_{50}$ values in GAE and ULE were $136.3 \pm 0.28 \mathrm{ppm}$ and $462.6 \pm 2.44 \mathrm{ppm}$, respectively. These indicate that the extract contents was dominated by semipolar compounds and polyphenol group such as tannin, chlorophyll and carotenoids [41].

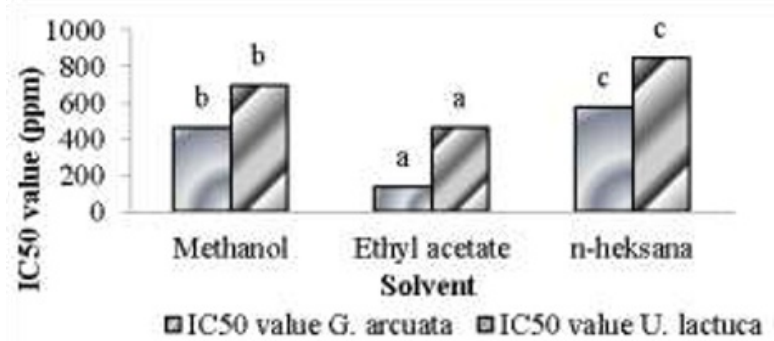

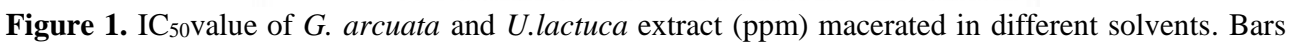
with different letters indicate the significantly difference $(\mathrm{p}<0.05)$.

There was a significant difference in $\mathrm{IC}_{50}$ values in two extract of $G$. arcuata and U.lactuca. GAE has moderate antioxidant activity with $\mathrm{IC}_{50}$ value of $136.3 \pm 0.28$, while extract of ULE has a very weak antioxidant activity with $\mathrm{IC}_{50}$ values more than $400 \mathrm{ppm}$. Every species has a different compounds which affect its antioxidant activity and depends on extraction method, season, location and the species used in the study [42]. 
In this research, antioxidant activity of GAE was better than of G. verrucosa from Pok Tunggal water $\left(\mathrm{IC}_{50}=188.53 \mathrm{ppm}\right)$ [13], while antioxidant activity of ULE was still relatively low compared by $U$. lactuca extract [43] that have strong antioxidant activity $\left(\mathrm{IC}_{50}=60.975\right.$ ppm). The different result occurs because the antioxidant activity are varied, depends on the species of seaweed [44], location [45] and seasons [14], respectively. Antioxidant compound act as a hydrogen atom donor [46]. Antioxidant compounds can inhibit free radicals by turning them into less dangerous free radicals [47].

There are high correlation between antioxidant and total phenolic content. The ability to reduce free radicals is related to the hydroxyl groups present in phenol compounds [48]. The hydroxyl group function act as a contributor to hydrogen atoms. It will reacting with free radicals through the electron transfer mechanism. There is a strong correlation between total phenolic content and the antioxidant activity potential with correlation coefficients 0.93 [49], and known that $99 \%$ of antioxidant activity is the result of the phenol compounds contribution, whereas $1 \%$ is thought to be a contribution from other compounds that have antioxidant abilities [50]. It is well known that the antioxidant activity of seaweed extracts containing polyphenol components is due to their capacity to be donors of hydrogen atoms or electrons and to capture the free radicals [51][59].

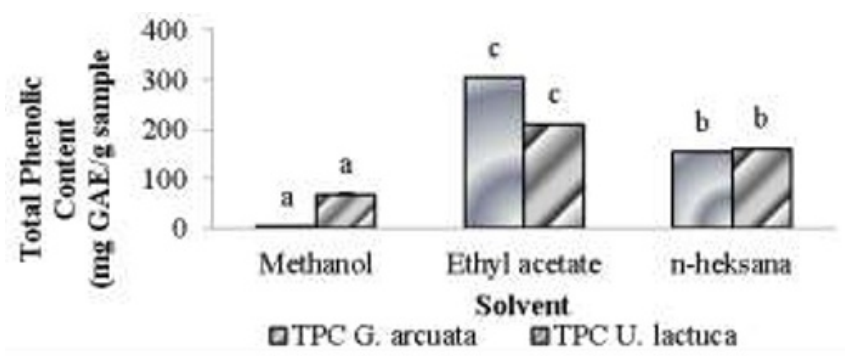

Figure 2. TPC value of G. arcuata and U.lactuca extract macerated in different solvents. Bars with different letters indicate the significantly difference $(\mathrm{p}<0.05)$.

Different extract had a different total phenolic compound (Figure 2.) Different phenolics can react differently to the Folin-Ciocalteu reagent, exhibiting lower absorption and hence leading to less estimation of phenolic compounds [52]. The highest content TPC were found in GAE (303,507 $\pm 1,155 \mathrm{mg}$ GAE/g sample) and $\operatorname{ULE}(210,129 \pm 1,387 \mathrm{mg}$ GAE/g sample). This result is much higher than G. gracilis ethyl acetate extract which is $35.53 \pm 1.47 \mathrm{mg}$ GAE/g sample [53]. And also higher than total phenolic compound of U. lactuca extract which is $56.8 \pm 14.5 \mathrm{mg} \mathrm{GAE} / \mathrm{g}$ sample [54]. The high content of this compound in ethyl acetate extract is thought to have a soluble polyphenols biocompounds such as tannins and flavanols.

Antioxidant activity can also be affected by pigment content. Chlorophyll a and carotenoids are extracted using organic solvents such as methanol, ethyl acetate and nhexane. It is because carotenoids are hydrophobic [55]. Hydrophobic is a property of a substance that repels water, lacking affinity for water, and tend to repel or not to absorb water. The results of G. arcuata and U.lactuca extract pigment (Figure 3.) shows that the highest chlorophyll a and carotenoid was reached by ethyl acetate. GAE extract contains $2,845 \pm$ $0,069 \mathrm{mg} / \mathrm{g}$ of chlorophyll and 0,528 $\pm 0,009 \mu \mathrm{mol} / \mathrm{g}$ carotenoids, while ULE extract contains $9,216 \pm 0,103 \mathrm{mg} / \mathrm{g}$ of chlorophyll and $0,442 \pm 0,046 \mu \mathrm{mol} / \mathrm{g}$ carotenoids.

The interest in carotenoids found in plants over the last years is not only due to their A provitamin activity but also due to their reduction of oxidative stress in the organism by capturing oxygen radicals. Carotenoids can inhibit active radicals by transferring electrons, giving hydrogen atoms to radicals or attaching to radicals [56]. 


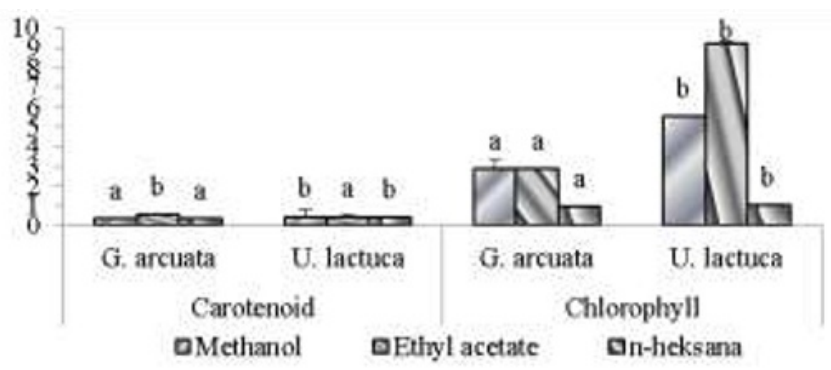

Figure 3. Pigment content of of G. arcuata and U.lactuca extract macerated in different solvents. Bars with different letters indicate the significantly difference $(\mathrm{p}<0.05)$.

Another pigment that have the same functions with carotenoid is chlorophyll. Chlorophyll is the main pigment found in seaweed and cooperate with carotenoid to absorb energy from the light [47]. Chlorophylls act as antioxidants to prevent oxidative DNA damage and lipid peroxidation both by chelating reactive ions and by scavenging free radicals [57]. The alterations in pigment concentration are determined by the interaction between two factors, light intensity and nutrient availability [58].

\section{Conclusion}

SPA extract was able to inhibit $46.12 \pm 2.03 \%$ of free radicals, contains total phenolic content $26.64 \pm 0.16 \mathrm{mg} \mathrm{GAE} / \mathrm{g}$ samples and dominated by phycocyanin pigments $(0.301 \pm 0.09$ $\mathrm{mg} / \mathrm{g}$ ). The best $\mathrm{IC}_{50}$ values, total phenolic content, chlorophyll a and carotenoid in $G$. arcuata and U.lactuca reached by ethyl acetate. It can be concluded that macroalgae extracted with ethyl acetate categorized as moderate antioxidant.

\section{References}

1. Nursid, M., Wikanta, T., Susilowati, R. 8, 1, 73-84 (2013)

2. Pangestuti, R., Siahaan, E.A., Kim, S.16, 399, 1-16 (2018)

3. Gumbo, J.R. And Nesamvuni, C.N. Journal of Chemical and Pharmaceutical Sciences, 10, 3, 1317-1325 (2017)

4. Hoseini, S.M., Khosravi, K., Mozafari, M.R. Mini-Reviews in Medicinal Chemistry, 13,1231-1237 (2013)

5. Asghari, A., Fazilati, M., Latifi, A.M., Salavati,H. J.Applied Biotechnology Reports, 3,1, 345-351 (2016)

6. Satyalakshmi, S. Asian J Pharm Clin Res,10, 12, 274-279 (2017)

7. Zaid, A.A.A., Hammad, D.M., Sharaf, E.M. International Journal of Pharmacology, 11,7, 846-851 (2015)

8. Nimse, S.B. and Pal, D. J.Royal Society of Chemistry, 5, 27986-28006 (2015)

9. Sahu, R.K., Kar M., Routray, R.. J.Med. Plants Stud, 1, 21-27 (2013)

10. Fitri, N. Jurnal Kefarmasian Indonesia, 1, 4, 41-50 (2013)

11. Parages, M.L., Rico, R.M., Abdala-Díaz, R.T., Chabrillón, M., Sotiroudis, T.G., Jiménez, C. J Appl Phycol, 24, 1537-1546 (2012)

12. Gad, A.S., Khadrawy, Y.A., El-Nekeety, A.A., Mohamed, S.R., Hassan, N.S. AbdelWahhab, M.A. Nutrition, 27, 582-589 (2011)

13. Febrianto, W., Djunaedi, A., Suryono, S., Santosa, G.W., Sunaryo, S. Jurnal Kelautan Tropis, 22, 1, 81-86 (2019). 
14. Khairy, H.M. and El-Sheikh, M.A. Saudi Journal of Biological Sciences, 22, 623630(2015)

15. Barot, M., Kumar, N., Kumar, R.N. Journal of Coastal Life Medicine, 4, 4, 284-289 (2016)

16. Moralez, M.E., Martinez, M.M., Gonzales, E., Ortis, C.M. Lat. Am. J. Aquat. Res, 46, 4, 709-716 (2018)

17. Thayag, C.M., Lin, Y., Lin, C., Liou, C., Chen, J. Fish \& Shellfish Immunology, 28, 764-773 (2010)

18. Hidayati, J.R., Ridlo, A., R. Pramesti. Buletin Oseanografi Marina, 6, 1, 46-52 (2017)

19. Alamsyah, H. K., Ita W., Agus S. Journal Of Marine Research, 3, 2, 69- 78 (2014)

20. Mardiyah, U., Fasya, A.G., Fauziyah, B., Amalia, S. Jurnal Alchemy, 3, 1, 39-46 (2014)

21. Banerjee, A., Dasgupta, N., De. B. J. food chem, 10, 4, 727-733 (2005).

22. Agustini, T.W., Suzeryb, M., Sutrisnanto, D., Ma'rufa, W.F., Hadiyanto. Procedia Environmental Sciences, 23, 282-289 (2015)

23. Norra, I., Aminah, A., Suri, R International Food of Research Journal, 23, 4, 1558 1563(2016)

24. Iltera, I., Akyıla, S., Demirelc, Z., Koçb, M., Conk-Dalayc M., Kaymak-Ertekina. Journal of Food Composition and Analysis, 70, 78-88 (2018)

25. Ghafar, M.F.A.,. Prasad, K.N., Weng, K.K., Ismail, A. African Journal of Biotechnology, 9, 3, 326-330 (2010)

26. Dere, S., Gunes, T. and Sivaci, R. Trends journal of Botany, 22, 13 (1998)

27. Fabrowska, J., Messyasz, B., Szyling, S., Walkowiak, J., Łęska1, B. Phycological Research. (2017)

28. Gross, J. Pigments In Vegetables. Chlorophylls and Carotenoids, An avi Book Van Nostrand Reinhold, New York. (1991)

29. Ridlo, A., Sedjati, S., Supriyantini E. Jurnal Kelautan Tropis, 18, 2, 58-63 (2015)

30. Saleha, M.; Dharb, W. and Singhb, K. Res. Biotechnol, 2, 2, 67-74 (2011)

31. Sarastani, D., Soekarto, S.T., Muchtadi, T.R., Fardiaz, D., Apriyantono, A. Jurnal Teknologi dan Industri Pangan, 13,2, 149-156 (2002)

32. Shipeng, Y., Woo, H., Choi, J., Park, Y., Chun, B. Fish AquatSci, 18, 2, 123-130

33. Molyneux, P.Sci.Techno.26, 212-219, (2004)

34. Nicklisch, S.C.T, Waite, J.H. MethodsX, 1, 233-238 (2014)

35. Hidayati, J.R., Yudiati, E., Pringgenies, D. Arifin, Z., Oktaviyanti, D.T. Jurnal Kelautan Tropis, 22, 1, 73-80 (2019)

36. Damar, A.C., Runtuwene, M.R.J., Wewengkang, D.S. Pharmacon, 3, 4, 11-21 (2014)

37. Delfan, P., Mortazavi, A., Rad, A.H.E.," Zenoozian, M.S. Food Process Technol, 9, 1 (2018)

38. Machu, L., Misurcova, L., Ambrozova, J.V., Orsavova, J., Mlcek, J., Sochor, J., Jurikova, T. Molecules, 20, 1118-1130 (2015)

39. Shalaby, E.A. and Shanab, S.M.M. Indian Journal of Geo-marine Sciences, 42, No. 5, 556-564 (2013)

40. Bermejo-Bescos, P., Pinero-Estrada, E. and. del Fresno, A.M.V. Toxicol. in Vitro, 22, 1496-1502 (2008)

41. Lailiyah, A., . Adi, T.K., Hakim, A., Yusnawan, E. J. Alchemy. 3, 1,18-30 (2014)

42. Budhiyanti, S.A., Raharjo, S., Marseno, D.W., lelana, I.Y.B. American Journal of Agricultural and Biological Sciences, 3, 7, 337-346 (2012)

43. Arbi, W., Ma'ruf, W.F., Romadhon. Saintek Perikanan, Vol.12, No.1, 12-18 (2016)

44. Parthiban, C., Saranya, C., Somasundaram, T., Anantharaman, P. International Journal of Phytopharmacy Research, 5, 1, 36-41 (2014)

45. Mirghani, M.E.S., Elnour, A.A.M., Kabbashi, N.A., Alam, M.Z., Musa, K.H., Abdullah, A. ScienceAsia, 44, 177-186 (2018) 
46. Sarini, AW., Aishah, HN, Zaini NM. International Conference on FoodEngineering and Biotechnology, 65, 51-56 (2014)

47. Sayuti, K. and Yenrina, R. Antioksidan Alami dan Sintetik. Andalas University Press, Padang (2015)

48. Mehdinezhad,N., Ghannadi,A.,Yegdaneh, A. Research inPharmaceutical Sciences, 11, 3, 243-249 (2016)

49. Barchan, A., Bakkali, M., Arakrak, A., Pagan, R., Lagloui, A Int.J.Curr.Microbiol.App.Sc, 3, 11, 399-412 (2014)

50. Gazali, M., Nurjanah, Zamani, N.P. JPHPI, 21, 1, 167-178, (2018)

51. Shon. M.Y., Kim, T.H. and Sung, J. Food Chem. 82, 4, 593-597 (2003)

52. Gironés-Vilaplana A., et al. Int J Food Sci Nutr Vol. 64, No. 7, 897-90.

53. Ebrahimzadeh, M.A., Khalili, M., Dehpour, A.A.J. Pharm. Sci, 54, 1. 1-6 (2018)

54. Marhuenda, J., Girones, A., Galvez, M., Mulero, J., Caravac, C., Zafrilla, P. Agro FOOD Industry Hi Tech, 27, 2, 57-59 (2016)

55. Saini, R.K., Keum, Y,S. J.Food Chemistry, 24, 90-103 (2018)

56. Kopsell, DA., Kopsell, DE. Trends in Plant Science, 11, 499-507 (2006)

57. Hsu BY., Pu YS., Inbaraj BS., Chen BH. An. Journal of Chromatograph, 899, 36-45 (2012)

58. Lapointe B.E., Ryther J.H. Aquaculture, 1978,15, 185-193 (1987).

59. Yudiati, E., Santosa, G.W., Tontowi, M.R., Sedjati, S., Supriyantini, E. \& Khakimah, M. 2018. IOP Conf. Ser.: Earth Environ. Sci., 139, 012052 (2018). 